\title{
Effect of cyanobacterial elicitor on neem cell suspension cultures
}

\author{
B. Poornasri Devi, A. Vimala, Isha Sai and S. Chandra * \\ Dept. of Biosciences, Sri Sathya Sai University, Anantapur Campus, Anantapur-5150 001, A.P., India \\ ${ }^{*}$ P. G. Dept. of Botany, Queen Mary's College, Chennai 600004, T.N. \\ b.psridevi@yahoo.com; laks1956@yahoo.co.in
}

\begin{abstract}
The present study aimed to elucidate the effect of cyanobacterial elicitor derived from Anabaena sp. and Nostoc carneum on neem cell suspensions evolved from superior callus lines of Azadirachta indica A. Juss elite $\mathrm{KN}-1$ accession with $12.88 \mathrm{mg} / \mathrm{gm}$ azadirachtin in its seed. Neem cell suspension cultures maintained in Murashige and Skoog liquid medium were treated with 265 cells $/ \mathrm{ml}$ and 530 cells $/ \mathrm{ml}$ homogenate of the elicitor on the third day. Growth of neem callus in terms of biomass revealed 5 fold enhancements when treated with 530 cells $/ \mathrm{ml}$ elicitor on tenth day in callus line- 1 . In callus line- 2 the log phase extended till tenth day recording a 6 fold increase with 265 cells $/ \mathrm{ml}$ elicitor concentration. The type of callus line and concentration of the elicitor influence the biomass growth of neem callus in suspension culture. Enhanced azadirachtin production was achieved by algal elicitor treatment (as confirmed by HPLC analysis) and this study makes a step forward towards industrial manufacturing of the neem alkaloid.
\end{abstract}

Keywords: Anabaena sp., Nostoc carneum, Neem, Azadirachtin, Elicitor, Suspension Culture.

Introduction

Secondary metabolites such as alkaloids, flavanoids, glycosides, oils, tannins, resins are isolated from wild or cultivated plants because their chemical synthesis is economically infeasible. Plant cells show physiological and morphological responses to microbial, physical or chemical factors which are known as 'elicitors'. Elicitation is a process of induced or enhanced synthesis of secondary metabolites by the plants to ensure their survival persistence and competitiveness. Elicitors are abiotic and biotic, or on their basis of 'origin' like exogenous elicitors and endogenous elicitors. Abiotic elicitors are the substances of nonbiological origin, i.e. inorganic salts and physical factors acting as elicitors like $\mathrm{Cu}^{2+}$ and $\mathrm{Cd}^{2+}$ ions, $\mathrm{Ca}^{2+}$ and high $\mathrm{pH}$, where as biotic elicitors are substances of biological origin including polysaccharides derived from plant cell walls (pectin or cellulose) and microorganisms (chitin or glucans and glycol proteins or G-proteins or intercellular proteins). Exogenous elicitors are substances originated outside the cell like polysaccharides, polyamines and fatty acids, where as endogenous elicitors are substances originated inside the cell (Namdeo, 2007).
Elicitation of cell cultures with biotic elicitor and signal compounds has been recognized as an important strategy for enhancement of secondary metabolites (Savitha et al., 2006). The enhanced production of secondary metabolites from plant cell cultures through elicitation has opened up a new area of research which could have important economical benefits for pharmaceutical industry. Neem (Azadirachta indica A. Juss Family Meliaceae) has spread to many parts of the world in the tropical and subtropical regions where there is no frost. Various parts of the tree have been in use for several millennia for medicinal, pharmaceutical and agricultural purposes.

Azadirachtin, an important bio-pesticide is one of the most active principles obtained from the neem seeds. In order to overcome the difficulties concerning variation in its source, availability, genetic stability and maintenance of purity, in-vitro production (Prakash et al., 2006; Sujanya et al., 2008) through tissue culture techniques is considered to be suitable alternative. Biotic elicitors of fungal origin revealed to be effective on growth as well as the production of azadirachtin in neem cell suspension cultures. Since there is only a scanty reports regarding algal/cyanobacterial elicitors, the present investigation on the effect of cyanobacterial elicitor on neem cell suspension cultures was carried out to understand the biochemical responses of the plant cells when challenged by the elicitor.

The present study investigated the positive role of cyanobacterial elicitors (Anabaena sp. and Nostoc carneum) on the biomass and its protein content of neem cell suspensions and the efficiency of elicitor to enhance the production of azadirachtin.

\section{Material and Methods}

Experimental material

Elite neem accessions KN1 with high azadirachtin (AZ) $12.88 \mathrm{mg} / \mathrm{g}$, in its seed was identified after an extensive survey of Anantapur District, Andhra Pradesh, India from the provenance of Karnatakanagepalli.

\section{Surface sterilization of explants}

The in-vivo explants such as stems, immature embryos were washed with running water and dettol for 5 minutes and further rinsed with 5\% Extran MA 02 for 5 minutes. It is followed by several washes in running tap water for $30-45$ 
minutes. Further surface sterilization was carried out in the laminar airflow chamber where the explants were rinsed with $70 \%$ ethanol for 30 seconds and were subsequently sterilized with $0.1 \%$ mercuric chloride for 5 minutes for stem explants and 6 minutes for immature embryos. Finally the explants were washed twice with sterile distilled water for ten minutes per wash and used for inoculation.

\section{Establishment of $A Z$-rich callus cell lines}

KN1 superior callus line germplasms were established after initial screening. The cotyledons were removed carefully using a scalpel from the surface sterilized fruits and were inoculated on M.S medium (Murashige \& Skoog, 1962) supplemented with 3\% sucrose.

\section{Establishment of neem callus cell suspension cultures}

About $15-20 \mathrm{ml}$ of callus cell suspension was made out of $2.5 \mathrm{gm}$ of brownish friable callus homogenized in $100 \mathrm{ml}$ liquid medium. The suspension cultures were maintained at $90 \mathrm{rpm}$ on a rotary shaker at $25 \pm 2^{\circ} \mathrm{C}, 3000$ Lux and $16 / 8$ hours photoperiod or total dark period.

Cyanobacterial elicitor-preparation

Pure cultures of two cyanobacteria of Nostocaceae family, namely, Anabaena sp. and Nostoc carneum were cultured in Bold's Basal medium (Bischoff \& Bold, 1963). The algal/cyanobacterial density as assessed by haemocytometer count was 530/ml for Anabaena sp. and $1670 / \mathrm{ml}$ for Nostoc carneum. $10 \mathrm{ml}$ of the algal/cyanobacterial cultures were autoclaved at 15 $\mathrm{lb}$ pressure and $121^{\circ} \mathrm{C}$ temperature for 30 minutes and homogenised were used as elicitors.

Cyanobacterial elicitor- treatment

Two to three days old neem cell suspension cultures were treated with cyanobacterial elicitors of the following concentrations and their effect on biomass and other parameters were assessed periodically.

- Density of the elicitor Anabaena 265/ml and 530/ml

- Density of the elicitor Nostoc carneum 1670/ml Quantification of biomass growth

Biomass change was quantified in all the variants of cell suspensions established from in vitro callus lines of KN1 neem accessions. The various parameters scored for assessing biomass were: fresh weight, (packed cell weight/ settled cell weight) and dry weight.

Packed cell weight: A $2 \mathrm{ml}$ of algal/cyanobacterial cell suspension was withdrawn and centrifuged at $13,000 \mathrm{rpm}$ for $10 \mathrm{~min}$. The supernatant was discarded and the packed cell weight was recorded from the weight of the pellets representing under aseptic conditions.

Growth efficiency. The efficiency of growth was assessed by average growth rate (QX):

$\mathrm{QX}=$ (maximum cell density) - (initial cell density)/ (Initial cell density) (culture time in weeks). Specific Growth Rate: Specific growth rate $(\mu)$ was calculated from $(\operatorname{InX}-\ln X o)$ versus time (t) plot where, $X_{0}$ is the initial biomass at the time of inoculation, $X$ is the biomass concentration estimated by measuring the fresh weight on different days of culture and ' $t$ ' is time period of the culture during the log phase of the culture.

$$
\mu=\ln X-\ln X o / t
$$

Growth Index. It is the ratio of the net increase in biomass to the initial biomass over a given period of time $\mathrm{N}=$

$$
\frac{X_{f}-X_{1}}{X_{1}}
$$

$\mathrm{N}=$ Growth index (dimensionless number) $X_{f}=$

Final biomass $X_{1}=$ Initial biomass

Quantitative analysis of azadirachtin using HPLC

Azadirachtin production from in-vitro neem cell suspension cultures was quantified by HPLC analysis. The intracellular and extracellular components were homogenized using a high speed micro tissue homogenizer. The homogenized cell-free components were centrifuged at $13,000 \mathrm{rpm},-4^{\circ} \mathrm{C}$ for 10 minutes and extracted into HPLC grade methanol. The supernatant collected was filtered through Sep-pak C-18 cartridge. A portion of the filtrate was subjected to HPLC analysis on Shimadzu LC-AT series, the mobile phase being acetonitrile: water, $35: 65$ at a flow rate of $1 \mathrm{ml} / \mathrm{min}$ with reverse phase analytical Chromega $\mathrm{C}-18$ column $(50 \mathrm{~mm}$ length $X$ $4.6 \mathrm{~mm}$ diameter) or Phenomenex $\mathrm{C}-18$ column (250mm length $X 4.6 \mathrm{~mm}$ diameter) with azadirachtin retention time at 6.7 minutes or 19.5

Table 1. Effect of cyanobacterial elicitor (Anabaena sp.) on the biomass of cell suspension cultures of neem variety $K \mathrm{~N}-1$

\begin{tabular}{|c|c|c|c|c|c|c|}
\hline \multirow{3}{*}{$\begin{array}{c}\text { Duration } \\
\text { (in days) }\end{array}$} & \multicolumn{5}{|c|}{ Fresh weight (gms/l) } \\
\cline { 2 - 7 } & Control & $\begin{array}{c}265 \text { cells/ml } \\
\text { Elicitor* }^{*}\end{array}$ & $\begin{array}{c}530 \text { cells/ml } \\
\text { Elicitor }^{*}\end{array}$ & Control & $\begin{array}{c}265 \text { cells/ml } \\
\text { Elicitor }^{*}\end{array}$ & $\begin{array}{c}530 \text { cells/ml } \\
\text { Elicitor* }^{*}\end{array}$ \\
\cline { 2 - 7 } & $25.0 \pm 0.0$ & $25.0 \pm 0.0$ & $25.0 \pm 0.0$ & $25.0 \pm 0.0$ & $25.0 \pm 0.0$ & $25.0 \pm 0.0$ \\
\hline 1 & $111.6 \pm 4.0$ & $111.6 \pm 4.0$ & $111.6 \pm 4.0$ & $55.6 \pm 2.3$ & $55.6 \pm 2.3$ & $55.6 \pm 2.3$ \\
\hline 3 & $96.4 \pm 3.0$ & $87.9 \pm 2.4$ & $133.4 \pm 1.7$ & $144.3 \pm 4.5$ & $137.6 \pm 1.8$ & $62.5 \pm 2.1$ \\
\hline 10 & $25.0 \pm 2.0$ & $38.9 \pm 1.3$ & $104.6 \pm 2.8$ & $62.4 \pm 1.1$ & $155.7 \pm 3.2$ & $53.2 \pm 4.1$ \\
\hline
\end{tabular}

* Addition of elictor on 3rd day 
Table 2. Effect of cyanobacterial (Anabaena sp.) elicitor on the growth rate of cell suspension cultures of neem variety $K N-1$

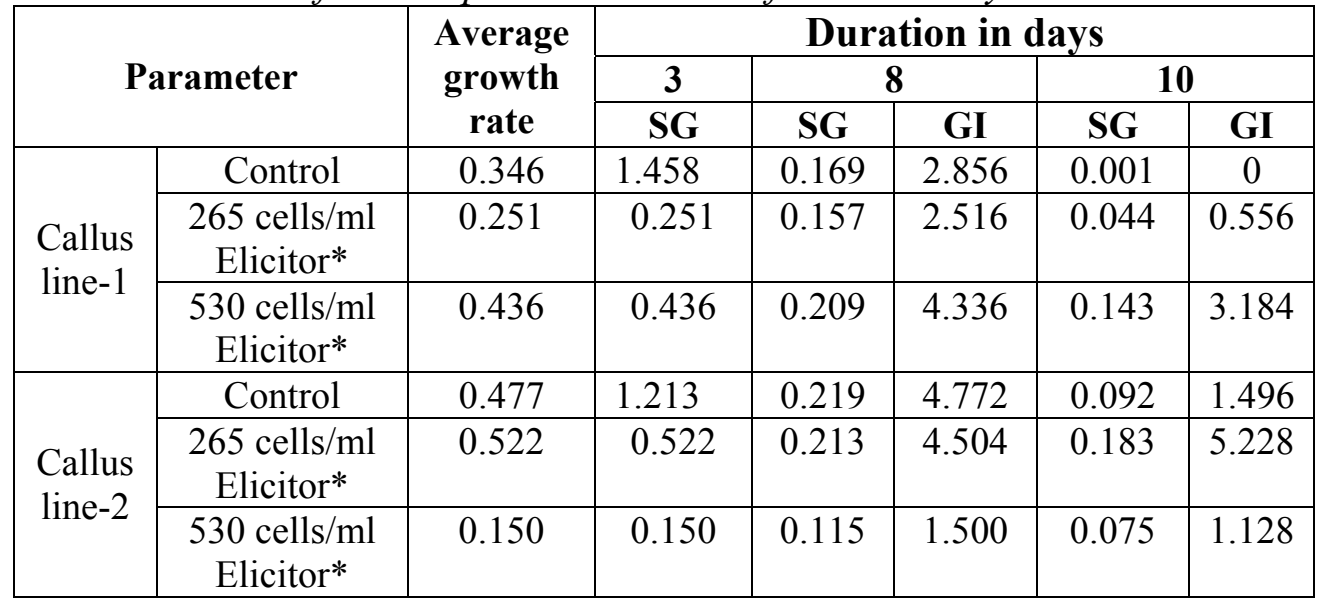

$S G$-Specific growth rate; GI-Growth index; *Addition of elicitor on $3 r d$ day minutes respectively. Azadirachtin was detected at 215nm by SPD-10AVP UV-VIS detector and quantified by comparing with the authentic (azadirachtin 95\%, Sigma, USA Catalogue No.A7430).

\section{Results}

Effect of cyanobacterial elicitor (Anabaena sp.) on the biomass and growth rate of cell suspension cultures of neem variety $K \mathrm{~N}-1$

A study using Anabaena $s p$. as elicitor on two cell lines in two concentrations i.e., 265cells $/ \mathrm{ml}$ and $530 \mathrm{cells} / \mathrm{ml}$ (Table1) revealed, 530cells $/ \mathrm{ml}$ concentration as optimum for biomass growth $(133.4 \mathrm{gm} / \mathrm{l})$ in callus line-1, whereas lower concentration $(265 / \mathrm{ml})$ of the elicitor gave optimal results in callus line-2 $(155.7 \mathrm{gm} / \mathrm{l})$. Growth index as given in Table-2 reveals 5.2 fold increase over the initial weight of the biomass which is highest when compared to any other concentration or growth period. Plant cell cultures take longer time (3-4 weeks) for doubling the growth with low growth rates (Ryu \& Lee, 1990). The algal/cyanobacterial elicitor is considered as an excellent biomass inducer compared to fungal elicitor (Vijayashree,

Table 3. Effect of cyanobacterial elicitor

(Nostoc carneum) on the biomass of cell

suspension cultures of neem variety $K N-1$

\begin{tabular}{|c|c|c|}
\hline $\begin{array}{c}\text { Duration } \\
\text { (in days) }\end{array}$ & \multicolumn{2}{|c|}{ Fresh weight (gms/l) } \\
\hline & Control & 1670 cells/ml elicitor* \\
\hline 0 & $25.0 \pm 0.00$ & $25 \pm 0.00$ \\
\hline 2 & $48.09 \pm 3.57$ & $60 \pm 5.16$ \\
\hline 3 & $46.0 \pm 6.00$ & $80 \pm 0.00$ \\
\hline 4 & $45.0 \pm 5.00$ & $55 \pm 5.00$ \\
\hline 5 & $40.0 \pm 6.00$ & $55 \pm 5.00$ \\
\hline 7 & $40.0 \pm 6.33$ & $50 \pm 4.14$ \\
\hline \multicolumn{3}{|c|}{ *Addition of elicitor on 2nd day } \\
\hline
\end{tabular}

$80 \mathrm{gm} / \mathrm{l}$ on $3 \mathrm{rd}$ day whereas in control it was maximum $(48.09 \mathrm{gm} / \mathrm{l})$ on 2 nd day of culture (Table 3). However, 2.2 folds increase of biomass by indicated by growth index 4th and 5th days of neem cell suspension cultures is exclusively due to algal elicitor (Table 4). Unlike fungi algae are autotrophic, though autoclaved sample is used as elicitor has revealed remarkable enhan-cement.

Enhancement of protein content in neem callus biomass using cyanobacterial elicit -ors

Since growing cell are actively involved in protein synthesis, the protein content of neem suspension callus due to growth induction by algal elicitors, is higher than that of control. Out of the two cyanobacterial elicitors, Anabaena induced higher growth rates than Nostoc carneum which is in tune to their relative enhanced growth indices (Table 5).

Effect of cyanobacterial elicitors on the production of azadirachtin in cell suspension cultures of Neem variety $\mathrm{KN}-1$

Anabaena sp. as elicitor at 265 cells $/ \mathrm{ml}$ on neem cell suspension cultures brought out a detectable amount of azadirachtin $(0.32 \mu \mathrm{g} / \mathrm{l})$ in the neem culture on eighth day (Table 6) while its other concentrations fail to achieve it. This is the first report where the cyanobacterial elicitors have shown positive role towards the production of tetranortriterpenoid, azadirachtin.

Discussion

Over few decades, many strategies like media manipulation, phyto-hormone regulation, precursor feeding, plant cell immobilization, biotransformation and bioconversion, hairy root cultures and genetically modified cells etc. have been tried, but failed to synthesize the desired products in appreciable quantity and at competitive economic value (Namdeo, 2007). Hence, elicitorbased enhancement of secondary metabolism in 
plants or plant cells in vitro provides an excellent opportunity for intensive research in the exploitation of plant cells for the production of secondary metabolites.

Table 4. Effect of cyanobacterial (Nostoc carneum) elicitor on the growth rate of cell suspension cultures of neem variety KN1

\begin{tabular}{|c|c|c|c|c|c|c|c|}
\hline \multirow[t]{2}{*}{ Parameter } & \multirow{2}{*}{$\begin{array}{c}\text { Average } \\
\text { growth } \\
\text { rate }\end{array}$} & \multicolumn{5}{|c|}{$\begin{array}{l}\text { Specific growth rate } \\
\text { (Duration in days) }\end{array}$} & \multirow{2}{*}{$\begin{array}{c}\text { Growtl } \\
\text { index }\end{array}$} \\
\hline & & 2 & 3 & 4 & 5 & 7 & \\
\hline Control & 0.478 & 0.336 & 0.203 & 0.147 & 0.094 & 0.094 & 0.956 \\
\hline $\begin{array}{l}\text { 1670cells/ } \\
\text { ml elicitor* }\end{array}$ & 0.860 & 0.438 & 0.389 & 0.197 & 0.197 & 0.099 & 2.200 \\
\hline
\end{tabular}

Cyanobacterial elicitor i.e. Anabaena sp. can be a potential source increasing the neem callus biomass to five folds which otherwise difficult to achieve. Elicitor concentration 265 cells $/ \mathrm{ml}$ of Anabaena $s p$. revealed $0.32 \mu \mathrm{l}$ azadirachtin on 8th day during the log phase. Unlike fungi, algae are autotrophic, though autoclaved sample is used as elicitor it has revealed remarkable enhancement on growth. However, further studies on type and concentration of algal elicitor may yield positive results on $A Z$ production.

Table 5. Enhancement of protein content in neem callus biomass using cyanobacterial elicitors

\begin{tabular}{|l|l|c|}
\hline \multicolumn{2}{|c|}{ Sample } & \multicolumn{1}{c|}{$\begin{array}{c}\text { Protein } \\
\text { content mg/ml }\end{array}$} \\
\hline \multicolumn{2}{|c|}{} & \\
\hline $\begin{array}{l}\text { Without } \\
\text { elicitor }\end{array}$ & Control & 6 \\
\hline $\begin{array}{l}\text { Cyanobacterial } \\
\text { elicitor }\end{array}$ & $\begin{array}{l}\text { Nostoc } \\
\text { carneum }\end{array}$ & 13 \\
\cline { 2 - 3 } & Anabaena sp. & 19 \\
\hline
\end{tabular}

Production of azadirachtin from suspension cultures of Azadirachta indica using fungal elicitor had been attempted by quite a number of investigators (Satdive et al., 2007; Sevon et al., 2002). Elictors of both fungal and bacterial origin

Table 6. Effect of cyanobacterial elicitors on the production of azadirachtin in cell suspension cultures of neem variety $K N-1$

\begin{tabular}{|c|c|c|c|c|c|}
\hline \multirow{2}{*}{ Parameter } & \multicolumn{5}{|c|}{ Amount of azadirachtin $(\mu \mathrm{g} / 1)$} \\
\cline { 2 - 6 } & $2^{\text {nd }}$ day & $4^{\text {th }}$ day & $6^{\text {th }}$ day & $8^{\text {th }}$ day & $10^{\text {th }}$ day \\
\hline Control & nil & nil & nil & nil & nil \\
\hline $\begin{array}{c}265 \text { cells/ml } \\
\text { Elicitor* }\end{array}$ & nil & nil & nil & 0.32 & nil \\
\hline $\begin{array}{c}530 \text { cells/ml } \\
\text { Elicitor* }\end{array}$ & nil & nil & nil & nil & nil \\
\hline $\begin{array}{c}1670 \text { cells/ml } \\
\text { Elicitor** }\end{array}$ & nil & nil & nil & nil & nil \\
\hline
\end{tabular}

* Anabaena sp.; **Nostoc carneum

iSee(C) category: Research article Indian Society for Education and Environment wall polysaccharides being the alginate would react with the oxidative burst Lamouroux, (in Laminaria $s p$.) had been shown to play a crucial role in controlling the growth of epiphytic and pathogenic bacteria producing hydrogen peroxide to reduce the bacterial growth and to reduce the number of microorganisms on algal surfaces (Kupper et al., 2006). A lone investigation reporting on marine red agarophyte Gracilaria conferta (Weinberger and Friedlander, 2000) indicated a low molecular weight (700-1500 DA) peptide was responsible as elicitors.

The major light harvesting pigment, phycocyanin of Spirulina platensis was used as an elicitor to enhance the accumulation of capsaicin and anthocyanin in Capsicum frutescens and Daucas carota cell cultures respectively. Two-fold increase of capsaicin in Capsicum frutescens and of anthocyanin in Daucas carota was obtained. Phycocyanin showed an early elicitation of secondary metabolites (Rao et al., 1996).

Early events in the perception of liposaccharides in the brown alga, Laminaria digitata include an oxidative burst and activation of fatty acid oxidation cascades. Oligosaccharide elicitors may be good candidates for a new type farm chemical for disease control. They are natural products and recyclable in the ecosystem. The laminarin polysaccharide of Laminaria when treated for tobacco plants showed resistance against pathogenic bacteria Erwinia cartovora which causes soft rot disease. Laminarin similarly induced defense responses in suspension cultured- grape vine cells and conferred resistance against pathogenic fungi Plasmopora viticola, which is causative agent of powdery mildew disease (Aziz et al., 
2003). Oligomer of sulphated fucan of Fucus brown marine alga was shown to induce defense response in Tobacco against Tobacco mosaic virus (Klarzynski et al., 2003).

Owing to the medicinal, pharmaceutical and agricultural importance of Azadirachta indica, the present study creates a new avenue for enhancement of bio-pesticide azadirachtin production using particularly algal/cyanobacterial elicitors.

\section{References}

1. Aziz A, Poinssot B, Dairex, Adrian M, Bezier A, Lambert B, Joubert JM, Pugin A. (2003) Laminarin elicits defense responses in Grapevine and induces protection against Botrytis cinerea and Plasmopora viticola. Molecular Plant-Microbe Interactions. 16, 1118-1128.

2. Bischoff HW and Bold HC (1963) Phycological studies. IV. Some algae from Enchanted Rock and related algal species. The Univ. of Texas Pub. No. 6318. 95 pp.

3. Klarzynski O, Descamps V, Pless B, Yvin JC, Kloareg B and Fritig B. (2003) Sulphated Fucan oligosaccharides elicit defense responses in Tobacco and local and systemic resistance against tobacco mosaic virus. Molecular Plant-Microbe Interactions. 16, 115122.

4. Kupper FC, Gaquerel E, Boneberg EM, Morath S, Salaun JP and Potin P (2006) Early events in the perception of lipopolysaccharides in the brown alga Laminaria digitata include an oxidative burst and activation of fatty acid oxidation cascades. J. Exptl. Botany. 57 (9), 1991-1999. doi:10.1093/jxb/erj146

5. Murashige T and Skoog E (1962) A revised medium for rapid growth and bioassay with tobacco tissue cultures. Physiol. Plant. 15, 473-497.

6. Namdeo AG (2007) Plant cell elicitation for production of secondary metabolites: A review. Pharmacognosy Reviews. Vol. 1, 69-79.

7. Prakash G and Srivastva AK (2006) Modeling of azadirachtin production by Azadirachta indica and its use for feed forward optimization studies. Biochem. Eng. J. 29, 62-68.

8. Rao SR, Sarada R and Ravishankar GA (1996) Phycocyanin, a new elicitor for capsaicin and anthocyanin accumulation in plant cell cultures. Appli. Microbiol. Biotechnol. 46, 619621.

9. Ryu DD and Lee SO (1990) Determination of growth rate for plant cell cultures: Comparative studies. Biotechnol. Bioengn. 35, 305-311.

10. Satdive RK, Fulzele DP and Eapen S (2007) Enhanced production of azadirachtin by hairy root cultures of Azadirachta indica A. Juss by elicitation and media optimization. $J$. Biotechnol. 128 (2), 281-289.

11. Savitha BC, Timmaraju $R$, Bhagyalakshmi $N$ and Ravishankar, GA (2006) Different biotic and abiotic elicitors influence betalin production in hairy root cultures of Beta vulgaris in shake flask and bioreactor. Process Biochem. 41, 50-60.

12. Sevon N and Oksman-Caldentey KM (2002) Agrobacterium rhizogenes mediated transformation: Root cultures as a source of alkaloids. Planta Med. 68, 859-868.

13. Sujanya S, Devi BP and Sai I (2008) In vitro production of azadirachtin from cell suspension cultures of Azadirachta indica. J. Biosci. 33, 113-120.

14. Vijayashree ASVB (2007) Production of azadirachtin in cell suspension cultures of neem (Azadiracta indica A. Juss). M.Sc. Dissertation, Sri Sathya Sai University, Prasanthinilayam.

15. Weinberger $F$ and Friedlander $M$ (2000) Endogenous and exogenous elicitors of a hypersensitive response in Gracilaria conferta (Rhodophyta). J.Appl. Phycol. 12, 139-145. 